\title{
The impact of bacterial contamination of the ejaculate and extender on the quality of swine semen doses
}

\section{O impacto da contaminação bacteriana do ejaculado e do diluente na qualidade das doses inseminantes de suínos}

\author{
Ana Maria Groehs Goldberg ${ }^{1}$; Marisa Cardoso ${ }^{2}$; Mari Lourdes Bernardi ${ }^{3}$; \\ Ivo Wentz ${ }^{4}$; Fernando Pandolfo Bortolozzo ${ }^{*}$
}

\begin{abstract}
The aim of this study was to verify the influence of the degree of bacterial contamination of boar ejaculate and semen extender on the quality of semen doses. The experiment was conducted in four boar studs, from which raw semen and two semen doses from each ejaculate were collected to evaluate the number of colony-forming units (CFU), $\mathrm{pH}$, sperm morphology and motility. Extender samples were also evaluated for CFU. Ejaculates that had higher levels of contamination $\left(>220 \mathrm{CFU} \mathrm{mL}^{-1}\right)$ resulted in semen doses with a greater degree of bacterial contamination but with no reduction in motility or alteration in $\mathrm{pH}$. When the semen doses were classified according to the degree of contamination of the extender, a decrease in motility was observed after 108 and $168 \mathrm{~h}$ of storage $(\mathrm{P}<0.05)$ in the group whose extender had $\geq 14,000 \mathrm{CFU} \mathrm{mL}^{-1}$ versus the group whose extender had $\leq 330 \mathrm{CFU} \mathrm{mL}^{-1}$. The $\mathrm{pH}$ remained stable during $168 \mathrm{~h}$ of storage in semen doses with extender that had lower contamination levels, but decreased from 7.2 to 6.0 between 24 and $168 \mathrm{~h}$ of storage $(\mathrm{P}<0.05)$ in the group with extender that had higher levels of contamination. A higher number of abnormal acrosomes $(\mathrm{P}<0.05)$ was observed after $168 \mathrm{~h}$ of storage in the semen doses whose extender was highly contaminated. The production of semen doses with low bacterial contamination and high sperm cell viability will only be possible with a strict hygienic control in semen processing, primarily with respect to the extender, combined with minimal contamination during collection.
\end{abstract}

Key words: Boar. Coliforms. Ejaculate contamination. Total mesophiles.

\section{Resumo}

O objetivo desse estudo foi verificar a influência do grau de contaminação bacteriana do ejaculado do macho suíno e do diluente na qualidade das doses inseminantes. O estudo foi conduzido em quatro centrais de inseminação, onde foram colhidas amostras de sêmen fresco e duas doses inseminantes produzidas a partir de cada uma das referidas amostras de sêmen. As amostras foram avaliadas quanto ao número de Unidades Formadoras de Colônia (UFC) de bactérias mesófilas totais e coliformes, pH, morfologia espermática e motilidade. As amostras de diluente também foram avaliadas quanto ao número de bactérias mesófilas. Ejaculados que apresentaram grau mais elevado de contaminação bacteriana ( > $220 \mathrm{UFC} \mathrm{mL}^{-1}$ ) resultaram em doses inseminantes com maior nível de contaminação bacteriana, porém não houve redução de motilidade ou alteração de pH. Quando as doses inseminantes foram classificadas

\footnotetext{
${ }^{1}$ Mestre em Ciências Veterinárias, Universidade Federal do Rio Grande do Sul, UFRGS, Porto Alegre, RS, Brasil. E-mail: agroehs@gmail.com

2 Prof., Departamento de Medicina Veterinária Preventiva, Faculdade de Veterinária, UFRGS, Porto Alegre, RS, Brasil. E-mail: mcardoso@ufrgs.br

${ }^{3}$ Profa, Departamento de Zootecnia, Faculdade de Agronomia, UFRGS, Porto Alegre, RS, Brasil. E-mail: mari.bernardi@ufrgs.br

${ }^{4}$ Profs., Setor de Suínos, Faculdade de Veterinária, UFRGS, Porto Alegre, RS, Brasil. E-mail: ivowentz@ufrgs.br; fpbortol@ufrgs.br

* Author for correspondence
} 
de acordo com a contaminação do diluente, um decréscimo na motilidade foi observado após 108 e 168 horas de armazenamento $(\mathrm{P}<0,05)$ no grupo em que o diluente apresentava $\geq 14.000 \mathrm{UFC} \mathrm{mL}^{-1} \mathrm{se}$ comparado com o observado no grupo cujo diluente apresentava $\leq 330 \mathrm{UFC} \mathrm{mL}^{-1}$. O pH permaneceu estável durante as $168 \mathrm{~h}$ de armazenamento em doses inseminantes que apresentavam diluentes com menor nível de contaminação, mas diminuiu de 7,2 para 6,0 entre 24 e 168 h de armazenamento $(\mathrm{P}<$ 0,05), no grupo com diluente que apresentava o maior nível de contaminação. Um número maior de acrossomas anormais $(\mathrm{P}<0,05)$ foi observado após $168 \mathrm{~h}$ de armazenamento em doses inseminantes cujo diluente era altamente contaminado. A produção de doses inseminantes com baixa contaminação bacteriana e alta viabilidade de células espermáticas só é possível com um estrito controle de higiene durante o processamento do sêmen, principalmente no que se refere ao diluente, combinado com uma contaminação mínima durante a coleta do sêmen.

Palavras-chave: Macho suíno. Coliformes. Contaminação do ejaculado. Mesófilos totais.

\section{Introduction}

Artificial insemination (AI) is the most widely used reproduction technology in swine breeding farms (ALTHOUSE et al., 2008). However, for a successful AI program, it is essential that boar studs produce high quality semen doses. In addition to the routine tests for evaluating sperm parameters (motility, morphology, sperm concentration), the production of semen doses should include microbiological analysis of water, extender and semen doses, as well as the quality control of laboratory hygiene and the contamination levels in samples of raw semen (WABERSKI et al., 2008).

According to Althouse and Lu (2005), the boar semen collection process is not a sterile procedure, and these authors suggest a protocol for semen collection with minimal contamination. Recently, it has been demonstrated that ensuring a lack of contact between the semen and the preputial liquid flowing through the glove is the most important procedure for obtaining ejaculates with a low bacterial contamination (GOLDBERG et al., 2013). Furthermore, some studies (KUSTER; ALTHOUSE, 1997; CLARK et al., 2007) have reported the importance of hygienic procedures in the processing line, especially regarding water and extender, as they are important sources of contamination of semen doses.

Semen doses with a high bacterial contamination tend to show sperm agglutination and reduced motility and viability, which contribute to return to estrus, vulvar discharge after insemination and reduced reproductive performance of the herd (ALTHOUSE et al., 2000). The aim of this study was to investigate the influence of the degree of bacterial contamination of raw boar semen and extender on the quality of semen doses.

\section{Materials and Methods}

The study was conducted on four commercial boar studs located in the south of Brazil, a region of major swine production. At the time of the study, 455 boars were kept in those studs, representing approximately $4 \%$ of the boar population in Brazil.

The evaluated boar studs followed the rules for swine breeding farms and were certified by the Brazilian Ministry of Agriculture. To become certified, the boar studs must be free of classical swine fever, Aujeszky's disease, brucellosis, tuberculosis and mange, in addition to being free of or at least controlled for leptospirosis. The boars were monitored for these diseases every 6 months, and negative results must be obtained to keep the aforementioned certification. The replacement animals were tested for these diseases before entering the stud. The animals were submitted to a 30-day isolation period, during which they were trained to have semen collected with the use of an artificial dummy.

Two visits were conducted, with an interval of three to four months in each boar stud. A total of $53,55,53$ and 52 semen collections, from 30, 32, 
32 and 28 boars, were performed in boar studs A, $\mathrm{B}, \mathrm{C}$ and $\mathrm{D}$, respectively, totaling 213 ejaculates. The ejaculates were collected by the gloved hand method using a low contamination protocol (BORTOLOZZO; WENTZ, 2005). After collection, the semen was taken to the boar stud laboratory where it was submitted to macro- and microscopic analyses (BORTOLOZZO; WENTZ, 2005), which were performed similarly in all boar studs.

After approval of the ejaculate, it was diluted in BTS (Beltsville Thawing Solution). In boar studs A, $\mathrm{B}$ and $\mathrm{C}$, the antimicrobial gentamicin $\left(200 \mathrm{mg} \mathrm{L}^{-1}-\right.$ IMVTM $^{\text {or }} 250 \mathrm{mg} \mathrm{L}^{-1}-$ Minitube $^{\mathrm{TM}}$ ) was added to the extender, whereas in the boar stud D, Linco-Spectin (260 $\mathrm{mg} \mathrm{L}^{-1}$ lincomycin and spectinomycin, Genes Diffusion $^{\mathrm{TM}}$ ) was used. The extender preparation and heating were performed in a stainless steel vat with a disposable plastic bag in boar studs A and D, whereas a PVC vat without an inner liner was used in boar studs B and C. All semen doses were semiautomatically packed into tubes of $100 \mathrm{~mL}$ capacity. The water used in the prepared extender was from an artesian well for all boar studs; however, for three of the studs, the purification was carried out with a reverse osmosis apparatus with a UV light, but for boar stud D, the water was filtered, deionized and distilled.

Samples of raw semen, collected in a sterile way, and two semen doses, prepared according to the stud protocol, were evaluated for microbiological quantification, $\mathrm{pH}$, sperm morphology and motility. Water and extender samples were also collected in a sterile way for microbiological quantification. The samples of raw semen and extender were transported at $5^{\circ} \mathrm{C}$, whereas the semen doses were transported in an insulated box with a controlled temperature $\left(16 \pm 2^{\circ} \mathrm{C}\right)$ for further analyses.

In the laboratory, a $12 \mathrm{~mL}$ aliquot was sterilely removed from the semen doses after gentle mixing for subsequent microbiological quantification; these aliquots were stored together with the other doses at $16^{\circ} \mathrm{C}$ for $168 \mathrm{~h}$. Other materials for microbiological evaluation were cooled to $5^{\circ} \mathrm{C}$. Samples of raw ejaculate, extender and semen doses stored for
48 and $168 \mathrm{~h}$ were evaluated to quantify aerobic mesophiles and total coliforms by the pour plate count method in PCA (Plate Count Agar, Oxoid) and VRB (Violet Red Bile Lactose Agar, Oxoid) culture media, respectively, according to FDA (1998). All samples were diluted up to $10^{-2}$ in a $0.85 \%$ sterile saline solution and plated in duplicate (1.0 $\mathrm{mL}$ inoculum of each dilution per plate). After incubation $\left(37^{\circ} \mathrm{C}\right.$ for $\left.48 \mathrm{~h}\right)$ in PCA medium, all colonies were counted; in the case of the VRB medium, only the colonies considered typical of coliforms were counted $(1-2 \mathrm{~mm}$ diameter, red with a pink precipitation halo). The number of colony-forming units per milliliter $\left(\mathrm{CFU} \mathrm{mL} \mathrm{m}^{-1}\right)$ was calculated by multiplying the average number of colonies counted in duplicate by the reciprocal of the dilution at which the count was performed.

Sperm morphology evaluation (BLOM, 1972) was performed in raw semen. Acrosome morphology (PURSEL et al., 1972) was evaluated in semen doses stored for 24 and $168 \mathrm{~h}$. The samples were fixed in a citrate-formalin solution, and 200 cells per sample were evaluated in a contrast phase microscopy (1000x).

The semen doses were evaluated for $\mathrm{pH}$ and motility at 24, 72, 108 and $168 \mathrm{~h}$ of storage. For the evaluation of $\mathrm{pH}$, a $3.0 \mathrm{~mL}$ aliquot was removed from each semen dose after gentle mixing; the sample remained at room temperature for approximately 30 min, after which the measurement was performed using a table $\mathrm{pH}$-meter (Schott, pH-meter CG825). For the motility evaluation, an aliquot of $1.5 \mathrm{~mL}$ was packed in an Eppendorf tube type after gentle mixing and heated to $38.0^{\circ} \mathrm{C}$ in a preheating table containing an aluminum block for supporting the plastic tubes. After $15 \mathrm{~min}$, the sample was gently mixed, and $2 \mu \mathrm{L}$ was inserted by capillarity into a $38^{\circ} \mathrm{C}$ disposable counting chamber (Leja ${ }^{\circledR}$ Slides), checking to ensure it was completely filled. The motility was evaluated in the longitudinal axis of the central portion of the chamber, starting from the opposite side of the opening, in less than $45 \mathrm{~s}$ using the Sperm Vision ${ }^{\mathrm{TM}}$ program $\left(\right.$ Minitub $^{\mathrm{TM}}$ ) with a negative phase contrast microscopy (200x). A cell 
count was performed in seven different fields with a maximum standard deviation of $15 \%$ in cell number between fields. The cells were identified by areas of the head between $20-120 \mu \mathrm{m}^{2}$. The spermatozoa were classified as immobile when the average orientation change of the head (AOC) had an angle of less than 2.5 degrees, with local movement when the straight line distance (DSL) was less than $4 \mu \mathrm{m}$ and having a progressive motility when cells did not fit in any of the previous classifications. Moreover, the sperm count was performed in semen doses after $24 \mathrm{~h}$ of storage so that the sperm:bacteria ratio could be determined.

Statistical analyses were performed using the SAS statistical software (SAS, 2000), and the descriptive analysis of data was performed using the MEANS and FREQ procedures. One analysis took into account the degree of extender contamination and its effect on the quality of semen doses: CFU $\mathrm{mL}^{-1} \leq 330(\mathrm{n}=105)$ and $\mathrm{CFU} \mathrm{mL}^{-1} \geq 14,000(\mathrm{n}=$ 108). There were no extender samples with level of contamination intermediate to these two limit values. Total motility, progressive motility and $\mathrm{pH}$ were analyzed as repeated measures using the MIXED procedure. This model included the fixed effects of the degree of extender contamination, the moment of evaluation and their interaction. The percentage of abnormal acrosomes at 24 and 168 $\mathrm{h}$ of storage were subjected to analysis of variance using the GLM procedure.

In another analysis, the ejaculates of boar studs $A$ and $\mathrm{D}$ were used as they did not have the extender contamination problem. In this analysis, the degree of contamination of semen doses $\left(\mathrm{CFU} \mathrm{mL} \mathrm{mL}^{-1}\right)$ was evaluated according to the degree of contamination of the raw ejaculate, which was separated into two

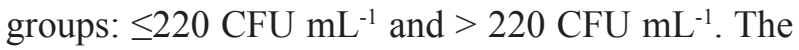
separation into these two groups was based on the median value of CFU $\mathrm{mL}^{-1}$ observed in the ejaculates evaluated in the four boar studs. For the analyses of the number of $\mathrm{CFU} \mathrm{mL} \mathrm{m}^{-1}$, the data were transformed logarithmically before being subjected to analysis of variance using the GLM procedure. The Chi- square test was used to compare the percentages

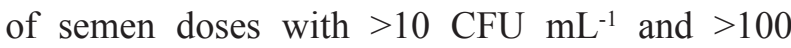
CFU mL ${ }^{-1}$ in PCA culture media at 48 and $168 \mathrm{~h}$, respectively. Total motility, progressive motility and $\mathrm{pH}$ were analyzed as repeated measures using the MIXED procedure. The fixed effects of raw semen contamination degree, the moment of evaluation and their interaction were included in the statistical model.

In all of the analyses of variance, the means were compared at a 5\% significance level using the t-test (two means) or the Tukey-Kramer test (more than two means).

\section{Results and Discussion}

The information related to the degree of bacterial contamination by aerobic mesophiles (PCA) or total coliforms (VRB) and the percentage of ejaculates with low bacterial contamination or considered free of microorganisms for the four boar studs are presented in Table 1. The consequences of the greater degree of extender contamination on motility, $\mathrm{pH}$ and acrosomal morphology in semen doses stored for $168 \mathrm{~h}$ are presented in Table 2. The results confirm that bacterial contamination led to the decline in motility, $\mathrm{pH}$ acidification and acrosome abnormalities as reported by several authors (KUSTER; ALTHOUSE, 1997; ALTHOUSE et al., 2000; ALTHOUSE; LU, 2005; ALTHOUSE, 2008; ALTHOUSE et al., 2008; GALL, 2008). The reduction in total and progressive motility after $108 \mathrm{~h}$ of storage in the group with higher levels of contamination in the extender confirms that the effects of bacterial contamination on the quality of semen doses were not observed immediately, but required at least 36 to $48 \mathrm{~h}$ of storage for agglutination and motility reduction to be evident (ALTHOUSE et al., 2000). This time is necessary because these changes are dependent on the bacterial adherence to spermatozoa (MONGA; ROBERTS, 1994; DIEMER et al., 1996). 
Table 1. Descriptive analysis of aerobic mesophiles (PCA) and total coliforms (VRB) growth in raw semen and extender.

\begin{tabular}{|c|c|c|c|c|}
\hline \multirow{2}{*}{ Variables } & \multicolumn{4}{|c|}{ Boar Studs } \\
\hline & A & $\mathrm{B}$ & $\mathrm{C}$ & $\mathrm{D}$ \\
\hline Number of ejaculates & 53 & 55 & 53 & 52 \\
\hline $\mathrm{CFU} \mathrm{mL} \mathrm{m}^{-1}(\mathrm{PCA})^{\mathrm{a}}$ & $\begin{array}{c}2985.7 \\
\pm 6576.7\end{array}$ & $\begin{array}{c}2394.1 \\
\pm 6377.7\end{array}$ & $\begin{array}{c}729.7 \\
\pm 4110.3\end{array}$ & $\begin{array}{c}2433.0 \\
\pm 4704.0\end{array}$ \\
\hline $\mathrm{CFU} \mathrm{mL} \mathrm{m}^{-1}(\mathrm{VRB})^{\mathrm{a}}$ & $\begin{array}{c}1058.7 \\
\pm 3790.7\end{array}$ & $\begin{array}{c}842.4 \\
\pm 4242.6\end{array}$ & $\begin{array}{c}622 \\
\pm 4115.5\end{array}$ & $\begin{array}{c}703.9 \\
\pm 3463.4\end{array}$ \\
\hline$\leq 220 \mathrm{CFU} \mathrm{mL}^{-1}$ (PCA), \% (n) & $52.8(28)$ & $45.4(25)$ & $77.4(41)$ & $28.8(15)$ \\
\hline No growth (PCA), \% (n) & $7.5(4)$ & $3.6(2)$ & $37.7(20)$ & $1.9(1)$ \\
\hline No growth (VRB), \% (n) & $34.0(18)$ & $58.2(32)$ & $50.9(27)$ & $25(13)$ \\
\hline Extender & & & & \\
\hline $\mathrm{CFU} \mathrm{mL} \mathrm{L}^{-1}(\mathrm{PCA})^{\mathrm{b}}$ & $0-330$ & $14,000->30,000$ & $30,000->30,000$ & $15-53.5$ \\
\hline CFU mL $\mathrm{mL}^{-1}(\mathrm{VRB})^{\mathrm{b}}$ & 0 & $0-3400$ & $139->30,000$ & 0 \\
\hline
\end{tabular}

CFU: colony-forming units; PCA: Plate Count Agar; VRB: Violet Red Bile Lactose Agar.

${ }^{a}$ Data presented as the mean \pm standard deviation.

${ }^{\mathrm{b}}$ Minimum and maximum observed values.

Table 2. Total and progressive motility, $\mathrm{pH}$ and abnormal acrosomes in the semen doses according to the degree of bacterial contamination of the extender.

\begin{tabular}{lccc}
\hline Variables & Moment & $\begin{array}{c}\leq 30 \mathrm{CFU} \mathrm{mL}^{-1} \\
(\mathrm{n}=105)\end{array}$ & $\begin{array}{c}\geq 14,000 \mathrm{CFU} \mathrm{mL}^{-1} \\
(\mathrm{n}=108)\end{array}$ \\
\hline Total motility, \% & $24 \mathrm{~h}$ & $85.3 \pm 8.3^{\mathrm{c}}$ & $86.2 \pm 7.7^{\mathrm{c}}$ \\
& $72 \mathrm{~h}$ & $81.9 \pm 11.1^{\mathrm{cd}}$ & $84.7 \pm 7.6^{\mathrm{c}}$ \\
& $108 \mathrm{~h}$ & $78.4 \pm 14.4^{\mathrm{Ad}}$ & $64.6 \pm 20.8^{\mathrm{Bd}}$ \\
Progressive motility, \% & $168 \mathrm{~h}$ & $70.5 \pm 21.0^{\mathrm{Ae}}$ & $21.8 \pm 9.2^{\mathrm{Be}}$ \\
& $24 \mathrm{~h}$ & $68.0 \pm 16.6^{\mathrm{c}}$ & $72.9 \pm 15.6^{\mathrm{c}}$ \\
& $72 \mathrm{~h}$ & $61.1 \pm 18.1^{\mathrm{d}}$ & $61.5 \pm 17.3^{\mathrm{d}}$ \\
$\mathrm{pH}$ & $108 \mathrm{~h}$ & $58.1 \pm 21.2^{\mathrm{Ad}}$ & $33.3 \pm 20.4^{\mathrm{Be}}$ \\
& $168 \mathrm{~h}$ & $46.5 \pm 23.8^{\mathrm{Ae}}$ & $7.1 \pm 4.8^{\mathrm{Bf}}$ \\
& $24 \mathrm{~h}$ & $7.3 \pm 0.2^{\mathrm{A}}$ & $7.2 \pm 0.1^{\mathrm{Bc}}$ \\
& $72 \mathrm{~h}$ & $7.3 \pm 0.2^{\mathrm{A}}$ & $7.1 \pm 0.2^{\mathrm{Bd}}$ \\
Abnormal acrosomes, $\%$ & $108 \mathrm{~h}$ & $7.3 \pm 0.1^{\mathrm{A}}$ & $6.7 \pm 0.3^{\mathrm{Be}}$ \\
& $168 \mathrm{~h}$ & $7.3 \pm 0.1^{\mathrm{A}}$ & $6.0 \pm 0.3^{\mathrm{Bf}}$ \\
& $24 \mathrm{~h}$ & $9.8 \pm 6.5$ & $9.9 \pm 7.0$ \\
& $168 \mathrm{~h}$ & $22.3 \pm 17.6^{\mathrm{A}}$ & $48.3 \pm 22.6^{\mathrm{B}}$ \\
\hline
\end{tabular}

CFU: colony-forming units.

Data presented as the mean \pm standard deviation.

$\mathrm{A}, \mathrm{B}$ in the row indicate significant differences according to the degree of contamination of the extender $(\mathrm{P}<0.05)$.

$c, \mathrm{~d}, \mathrm{e}, \mathrm{i}$ in the column indicate significant differences among storage periods $(\mathrm{P}<0.05)$.

It is important to note that the $\mathrm{pH}$ of semen doses was affected by the degree of extender contamination (Table 2) but not by the raw semen contamination (Table 3 ). The $\mathrm{pH}$ remained stable for $168 \mathrm{~h}$ of storage in the group with a lower level of contamination in the extender but decreased from
7.2 to 6.0 between 24 and $168 \mathrm{~h}$ of storage, in the group with a more contaminated extender (Table 2). Possibly, this $\mathrm{pH}$ change contributed to the drastic reduction in total motility and progressive motility observed at $108 \mathrm{~h}$ onwards in the group with the high bacterial contamination of the extender. 
The $\mathrm{pH}$ change was likely a result of bacterial metabolites released into the medium, and control over this will be dependent on the buffer used in the extender. Althouse et al. (2000) observed that the $\mathrm{pH}$ ranged from 5.7 to 6.4 in $93 \%$ of contaminated samples with different bacterial genera, confirming that some bacterial genera produce substances that acidify the medium, whereas others appear to produce these substances in smaller quantities or not at all.

Table 3. Characteristics of semen doses (SD) according to the degree of contamination of raw semen (mean \pm standard deviation).

\begin{tabular}{|c|c|c|c|}
\hline \multicolumn{2}{|l|}{ Variables } & $\leq 220 \mathrm{CFU} \mathrm{mL}^{-1}(\mathrm{n}=43)$ & $>220 \mathrm{CFU} \mathrm{mL}^{-1}(\mathrm{n}=62)$ \\
\hline \multicolumn{2}{|c|}{ CFU mL $\mathrm{mL}^{-1}$ in raw semen $(\mathrm{PCA})^{\mathrm{a}}$} & $71.4 \pm 66.7^{\mathrm{C}}$ & $4543.4 \pm 6868.4^{\mathrm{D}}$ \\
\hline \multicolumn{2}{|c|}{$\mathrm{CFU} \mathrm{mL} \mathrm{mL}^{-1}$ in raw semen $(\mathrm{VRB})^{\mathrm{a}}$} & $8.6 \pm 15.5^{\mathrm{C}}$ & $1489.4 \pm 4628.1^{\mathrm{D}}$ \\
\hline \multicolumn{2}{|c|}{$\mathrm{CFU} \mathrm{mL} \mathrm{m}^{-1}$ in $\mathrm{SD}$ at $48 \mathrm{~h}(\mathrm{PCA})^{\mathrm{a}}$} & $99.1 \pm 228.5^{\mathrm{C}}$ & $421.5 \pm 2269.2^{\mathrm{D}}$ \\
\hline \multicolumn{2}{|c|}{$\mathrm{CFU} \mathrm{mL} \mathrm{mL}^{-1}$ in $\mathrm{SD}$ at $48 \mathrm{~h}(\mathrm{VRB})^{\mathrm{a}}$} & $0.0 \pm 0.0^{\mathrm{b}}$ & $110.7 \pm 613.6^{\mathrm{b}}$ \\
\hline \multicolumn{2}{|c|}{ SD with $>10 \mathrm{CFU} \mathrm{mL} \mathrm{L}^{-1}$ at $48 \mathrm{~h}, \%$ (n) } & $32.6(14)^{\mathrm{C}}$ & $61.3(38)^{\mathrm{D}}$ \\
\hline \multicolumn{2}{|c|}{$\mathrm{SD}$ with $>100 \mathrm{CFU} \mathrm{mL} \mathrm{mL}^{-1}$ at $168 \mathrm{~h}, \%$ (n) } & $58.1(25)$ & $47.5(29)$ \\
\hline \multicolumn{2}{|c|}{ Total motility in raw semen } & $86.9 \pm 2.4$ & $87.4 \pm 2.7$ \\
\hline \multirow[t]{4}{*}{ Total motility, $\%$} & $24 \mathrm{~h}$ & $83.8 \pm 8.7^{\mathrm{e}}$ & $86.4 \pm 7.9^{\mathrm{e}}$ \\
\hline & $72 \mathrm{~h}$ & $79.1 \pm 13.7^{\mathrm{Cf}}$ & $83.9 \pm 8.5^{\mathrm{Df}}$ \\
\hline & $108 \mathrm{~h}$ & $74.0 \pm 18.2^{\mathrm{Cg}}$ & $81.4 \pm 10.2^{\mathrm{Dg}}$ \\
\hline & $168 \mathrm{~h}$ & $64.5 \pm 21.5^{\mathrm{Ch}}$ & $74.7 \pm 19.8^{\mathrm{Dh}}$ \\
\hline \multirow[t]{4}{*}{ Progressive motility, $\%$} & $24 \mathrm{~h}$ & $65.4 \pm 18.5^{\mathrm{e}}$ & $69.9 \pm 15.1^{\mathrm{e}}$ \\
\hline & $72 \mathrm{~h}$ & $57.7 \pm 20.7^{\mathrm{f}}$ & $63.5 \pm 15.8^{\mathrm{f}}$ \\
\hline & $108 \mathrm{~h}$ & $53.4 \pm 25.1^{\mathrm{g}}$ & $61.4 \pm 17.5^{\mathrm{g}}$ \\
\hline & $168 \mathrm{~h}$ & $39.9 \pm 24.7^{\mathrm{Ch}}$ & $51.1 \pm 22.3^{\mathrm{Dh}}$ \\
\hline \multirow[t]{4}{*}{$\mathrm{pH}$} & $24 \mathrm{~h}$ & $7.4 \pm 0.2$ & $7.3 \pm 0.2$ \\
\hline & $72 \mathrm{~h}$ & $7.4 \pm 0.3$ & $7.3 \pm 0.2$ \\
\hline & $108 \mathrm{~h}$ & $7.3 \pm 0.1$ & $7.3 \pm 0.1$ \\
\hline & $168 \mathrm{~h}$ & $7.3 \pm 0.1$ & $7.3 \pm 0.1$ \\
\hline
\end{tabular}

CFU: colony-forming units; PCA: Plate Count Agar; VRB: Violet Red Bile Lactose Agar.

The analysis included ejaculates and semen doses from 2 boar studs in which contamination of the extender was $\leq 330 \mathrm{CFU} \mathrm{mL}^{-1}$.

${ }^{\text {a }}$ Data analyzed after logarithm transformation.

${ }^{\mathrm{b}}$ No comparison because there was no growth at $48 \mathrm{~h}$.

$\mathrm{C}, \mathrm{D}$ in the row indicate a significant difference $(\mathrm{P}<0.05)$.

$\mathrm{e}, \mathrm{f}, \mathrm{g}, \mathrm{h}$ in the column indicate significant differences among storage periods $(\mathrm{P}<0.05)$.

A higher number of abnormal acrosomes were observed after $168 \mathrm{~h}$ of storage in semen doses whose extender was highly contaminated (Table 2). By binding to spermatozoa, bacteria cause ultrastructural lesions in the plasma membrane (DIEMER et al., 1996), and the acrosomal integrity is compromised in most agglutinated sperm samples (KUSTER; ALTHOUSE, 1997). Bennemann et al. (2000) studied the effect of $S$. aureus and E. coli at different concentrations in semen doses on acrosome alterations and observed that after $48 \mathrm{~h}$ of storage

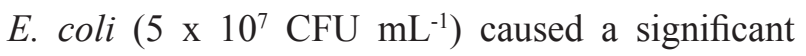
increase in abnormal acrosomes. Apparently, the time of onset of sperm changes and the magnitude of changes in $\mathrm{pH}$, motility and acrosome integrity are dependent on the bacterial genera and their concentration in the semen doses.

Bacteria isolated in the water purification systems (CLARK et al., 2007) are a potential source for the contamination of semen doses and the subsequent reproductive failure (PAYNE et al., 2008). Schulze et al. (2015) emphasize that the contamination of 
water, mainly with multidrug-resistant bacteria, is an important factor in their spread and is therefore a crucial area for control. Although water purification systems were not tested for microbiological contamination, it is possible that stored water used to prepare extenders was already contaminated in boar studs B and C, which had a high degree of extender contamination. The contamination of water may occur at its origin, along the water purification system (PAYNE et al., 2008) or in vats used for its storage. In boar studs B and C, PVC (Polyvinyl chloride) vats with a heating system were used for extender preparation. As these vats have several areas that are difficult to access for cleaning, the formation of biofilms inside the container could have taken place, allowing bacterial multiplication (SILVA et al., 2006). Indeed, Schulze et al. (2015) verified that bacteria colonize the inner surface of dilution tanks lids during semen processing. In the presence of biofilms, conventional disinfection methods are not sufficient, requiring the use of higher disinfectant concentrations, which usually leave residues (SILVA et al., 2006) that can be toxic to spermatozoa. For the studs A and D, in which semen doses were less contaminated, stainless steel vats were used; these contained a plastic bag inside that was disposed of at the end of each day, preventing biofilm formation.

Ejaculates more contaminated $\left(>220 \mathrm{CFU} \mathrm{mL}^{-1}\right)$ resulted in greater percentages of semen doses also more contaminated, after $48 \mathrm{~h}$ of storage (Table 3), in boar studs A and D. This result shows that when the processing environment is clean and there is a low bacterial contamination of the water or extender, the most likely source of contamination for semen doses is the raw semen. Although Althouse (2008) reported that the first step in reducing bacterial contamination of semen doses is to improve the hygiene of the boar and the collection procedure, Schulze et al. (2015) reported that bacterial species cultured from the extended semen were also isolated from the raw ejaculate in only $4.5 \%$ of the contaminated semen doses. Taken together, these observations emphasize the assumption that total cleanliness during all work phases (especially in areas with higher risks) is necessary to maintain the maximum level of hygiene for semen processing (WEITZE, 2008).

Bennemann (1998) demonstrated that an antimicrobial agent is capable of reducing the contamination of semen doses but cannot eliminate it. In his study, $99.1 \%$ of raw semen samples were contaminated, whereas $97.7 \%$ and $71.3 \%$ of semen doses were contaminated in the absence and presence of antimicrobial agents, respectively. In the present study, bacterial growth after $168 \mathrm{~h}$ of storage was not influenced by the degree of contamination of the ejaculate, thus confirming that the number of CFU increases during the storage, regardless of the presence of antimicrobials (BENNEMANN, 1998).

Spermatic alterations due to bacterial contamination are observed only after a sperm:bacteria ratio of 1:1 or greater is achieved (DIEMER et al., 1996; ALTHOUSE et al., 2000). Maximum ratios of 1450:1 at $48 \mathrm{~h}$ and 370:1 at 168 $\mathrm{h}$, observed in boar studs A and D, likely explain the absence of harmful effects of raw semen contamination on motility and the $\mathrm{pH}$ of semen doses. Apparently, to reach a sperm:bacteria ratio of $1: 1$, which can reduce the quality of semen doses, there must be a high degree of contamination in the water or extender, as mentioned in some studies (KUSTER; ALTHOUSE, 1997; CLARK et al., 2007). In the present study, the boar stud that had the greatest mean CFU $\mathrm{mL}^{-1}$ in raw semen showed a ratio greater than 100,000 sperm by CFU. Furthermore, when bacteria are introduced in a new environment, which occurs through semen dilution, they require a certain time for recovery and adaptation to metabolize the substrates present in the extender (ALTHOUSE, 2008). Bacteria can have difficulties in adapting and growing in the new environment (BENNEMANN et al., 2000) and, if they are sensitive to antimicrobial agents present in the extender, the contamination will probably be reduced. However, if the source of contamination 
is the extender itself, bacterial growth can be facilitated, as the bacteria are already fully adapted to the environment with an appropriate temperature and a high amount of substrate, in addition to the possible development of antimicrobial resistance.

If a ratio sperm: bacteria lower than 1:1 is taken into account as a hygiene parameter, the collection procedure can be viewed as satisfactory, as all raw semen samples were below this ratio value. However, the importance of a permanent hygienic control during semen processing was observed, if we consider what happened due to the extender contamination in boar stud $\mathrm{C}$. In this case, the presence of aerobic mesophiles in the raw semen

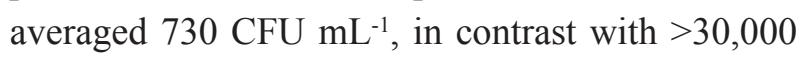
CFU $\mathrm{mL}^{-1}$ observed in the semen doses. Therefore, the degree of contamination of raw semen seems to have less of an effect on the quality of semen doses than situations in which the source of contamination comes from poor hygiene in the semen processing line. This aspect has been recently highlighted (SCHULZE etal., 2015) by the fact that in most cases, all of the samples from one stud were contaminated with identical bacteria, indicating contamination during semen processing. The production of semen doses with a high microbiological quality requires a strict care beyond the hygiene during semen collection, as raw semen with few CFU does not guarantee that semen doses will be free of contaminants. Bacterial concentrations that produce changes in agglutination, motility, $\mathrm{pH}$ and the acrosomes appear to occur more easily when water or extenders are contaminated. As high numbers of bacteria can be found in heating cabinets, ejaculate transfer, manual operating elements and laboratory surfaces (SCHULZE et al., 2015), the contamination can also take place during extender preparation and storage or along the processing line of semen doses. These contamination sources should be considered more important than raw semen because they will act on all processed semen doses and not only on semen doses produced by individually contaminated ejaculates.
Bacterial contamination of semen doses can be minimized by proper sanitary and laboratory practices in semen processing. The training and motivation of the laboratory staff are extremely important (ALTHOUSE, 2008; SCHULZE et al., 2015) so that personnel be aware of the hygienic critical control points for the reduction of microbiological contamination. Considering that water contamination can affect the quality of a large number of semen doses, the preventive maintenance of purification systems by regularly replacing the key elements that assure its good functioning is very important. Furthermore, water used for extender preparation, the extender itself and semen doses should be frequently tested for contaminants, at least once a month.

\section{Conclusions}

Bacterial contamination of raw semen has less of an impact on sperm viability than does the contamination of the extender. In addition to the importance of a minimal contamination protocol during semen collection, low contamination of semen doses and greater sperm viability will only be possible with a strict hygienic control in the semen processing line, especially in regards to the water used for the extender preparation.

\section{Acknowledgments}

The authors are grateful to CAPES (Comissão de Aperfeiçoamento de Pessoal do Nível Superior, Ministério da Educação, Brasil) for sponsoring the main author and to Minitub do Brasil for providing the Sperm Vision System to perform the analyses of semen.

\section{Conflict of Interest}

The authors declare that they have no conflict of interest. 


\section{References}

ALTHOUSE, G. C. Sanitary procedures for the production of extended semen. Reproduction in Domestic Animals, Malden, v. 43, p. 374-378, 2008. Supplement 2.

Althouse, G. C.; KUSTER, C. E.; ClARCK, S. G.; WEISIGER, R. M. Field investigations of bacterial contaminants and their effects on extended porcine semen. Theriogenology, Philadelphia, v. 53, n. 5, p. 1167-1176, 2000.

ALTHOUSE, G. C.; LU, K. G. Bacteriospermia in extended porcine semen. Theriogenology, Philadelphia, v. 63 , n. 2, p. 573-584, 2005.

Althouse, G. C.; PIERDON, M. S.; LU, K. G. Thermotemporal dynamics of contaminant bacteria and antimicrobials in extended porcine semen. Theriogenology, Philadelphia, v. 70, n. 8, p. 1317-1323, 2008.

BENNEMANN, P. E. Avaliação de doses inseminantes produzidas em centrais de inseminação artificial de suínos no sul do Brasil e o efeito da contaminação bacteriana sobre a qualidade espermática. 1998. Dissertação (Mestrado em Ciências Veterinárias) Faculdade de Medicina Veterinária. Universidade Federal do Rio Grande do Sul, Porto Alegre.

BENNEMANN, P. E.; BORTOLOZZO, F. P.; WENTZ, I.; CARDOSO, M. R. I. Motilidade espermática e integridade acrossomal em doses de sêmen suíno refrigeradas e inoculadas com Escherichia coli e Staphylococcus aureus. Ciência Rural, Santa Maria, v. 30, n. 2, p. 313-318, 2000.

BLOM, E. The ultrastructure of some characteristics sperm defects and a proposal for a new classification of bull spermiogram. In: SIMPOSIO INTERNAZIONALE DI ZOOTECNIA, 7., 1972, Milano. Proceedings... Milano: Società Italiana per il Progresso della Zootecnia, 1972. p. 125-139.

BORTOLOZZO, F. P.; WENTZ, I. Suinocultura em ação 2: inseminação artificial na suinocultura tecnificada. Pallotti: Porto Alegre, 2005. 183 p.

CLARK, S.; NESS, A.; PAYNE, B.; BORST, L.; MADDOX, C. Description of growth dynamics of biofilm bacteria found in extended porcine semen. Biology of Reproduction, Madison, v. 77, p. 84-85, 2007. Supplement 1.

DIEMER, T.; WEIDNER, W.; MICHELMANN, H. W.; SCHIEFER, H. G.; ROVAN, E.; MAYER, F. Influence of Escherichia coli on motility parameters of human spermatozoa in vitro. International Journal of Andrology, Malden, v. 19, n. 5, p. 271-277, 1996.

FOOD AND DRUG ADMINISTRATION - FDA. Bacteriological Analytical Manual. Silver Spring: FDA, 1998. Available at: <http://www.fda.gov/
Food/FoodScienceResearch/LaboratoryMethods/ ucm2006949. htm>. Access at: 26 june 2014.

GALL, T. Hygiene and contamination in the Lab. In: MIDWEST BOAR STUD MANAGERS CONFERENCE, 2008, St. Louis. Proceedings... St. Louis: University of Missouri, 2008. p. 93-100.

GOLDBERG, A. M. G.; ARGENTI, L. E.; FACCIN, J. E. G.; LINCK, L., SANTI, M.; BERNARDI, M. L.; CARDOSO, M. R. I.; WENTZ, I.; BORTOLOZZO, F. P. Risk factors for bacterial contamination during boar semen collection. Research in Veterinary Science, London, v. 95, n. 2, p. 362-367, 2013.

KUSTER, C.; ALTHOUSE, G. C. Sperm agglutination of extended semen caused by gentamicin-resistant bacteria. In: ANNUAL MEETING OF AMERICAN ASSOCIATION OF SWINE PRACTITIONERS, 28., 1997, Quebec. Proceedings... Quebec: American Association of Swine Practitioners, 1997. p. 293-295.

MONGA, M.; ROBERTS, J. A. Sperm agglutination by bacteria: receptor-specific interactions. Journal of Andrology, Philadelphia, v. 15, n. 2, p. 151-156, 1994.

PAYNE, B. J.; CLARK, S.; MADDOX, C.; NESS, A. Achromobacter xylosoxidans in extended semen causes reproductive failure in artificially inseminated sows and gilts. Journal of Swine Health and Production, Perry, v. 16, n. 6, p. 316-322, 2008.

PURSEL, V. G.; JOHSON, L. A.; RAMPACEK, G. B. Acrosome morphology of boar spermatozoa incubated before cold shock. Journal of Animal Science, Champaign, v. 34, n. 2, p. 278-283, 1972.

SCHULZE, M.; AMMON, C.; RÜDIGER, K.; JUNG, M.; GROBBEL, M. Analysis of hygienic critical control points in boar semen production. Theriogenology, Philadelphia, v. 83, n. 3, p. 430-437, 2015.

SILVA, C. H. P. M.; LINS, A. P.; CRUZ, C. S. O.; GREENBERG, W.; STEWART, T. Caracterização dos biofilmes formados em filtros de carvão ativado de sistemas de purificação de água em laboratórios clínicos. Revista Brasileira de Análises Clínicas, Rio de Janeiro, v. 38, n. 4, p. 243-253, 2006.

STATISTICAL ANALYSIS SYSTEM - SAS. SAS Institute INC. User's Guide: Statistical Analysis System. Version 8.0. Cary: SAS Institute INC, 2000.

WABERSKI, D.; PETRUNKINA, A. M.; TÖPFERPETERSEN, E. Can external quality improve pig AI efficiency? Theriogenology, Philadelphia, v. 70, n. 8, p. 1346-1351, 2008.

WEITZE, K. F. Hygiene tips for good semen quality. Pig International, Rockford, v. 38, n. 8, p. 14-16, 2008. 
